JURNAL BASICEDU

Research \& Learning in Elementary Education

https://jbasic.org/index.php/basicedu

\title{
Pengembangan Bahan Ajar Matematika Berbasis Problem Based Learning Pada Siswa Sekolah Dasar
}

Fida Lestari ${ }^{1}$, Asep Sukenda Egok ${ }^{2}$, Riduan Febriandi ${ }^{3}$

Program Studi Pendidikan Guru Sekolah Dasar, STKIP-PGRI Lubuklinggau

E-mail: fidalestari98@ gmail.com ${ }^{1}$, asep.egok91@ gmail.com ${ }^{2}$, riduanfebriandi9@gmail.com $^{3}$

\begin{abstract}
Abstrak
Penelitian ini bertujuan untuk mengembangkan sebuah produk berupa bahan ajar Mathematic berbasis Problem Based Learning pada siswa kelas V SD Negeri 37 Lubuklinggau sesuai dengan kurikulum 2013 serta untuk menghasilkan bahan ajar yang valid dan praktis untuk digunakan dalam belajar. Penelitian ini merupakan penelitian pengembangan dengan model pengembangan diadaptasi dari model Four-D. Berdasarkan hasil analisis penilaian oleh ketiga ahli yaitu: ahli bahasa, ahli materi, dan ahli media menunjukkan bahwa bahan ajar materi statistika berbasis problem based learning memenuhi kriteria valid dengan rata-rata skor 0,76 . Sedangkan hasil analisis penilaian lembar kepraktisan guru dan siswa yang terdiri dari 9 orang diperoleh bahwa bahan ajar materi statistika berbasis problem based learning memenuhi kriteria praktis dengan rata-rata skor 95\%, sehingga dapat disimpulkan bahwa bahan ajar materi statistika berbasis Problem Based Learning memenuhi kriteria valid, praktis dan bisa digunakan dalam pembelajaran.
\end{abstract}

Kata Kunci: Pengembangan, Bahan Ajar Matematika, Problem Based Learning.

\begin{abstract}
This study aims to develop teaching materials based on Mathematics Based Problem-Based Learning in fifth grade students of SD 37 Lubuklinggau in accordance with the 2013 curriculum and to produce valid and practical teaching materials for use in learning. This research is a development study with a development model adapted from the Four-D model. Based on the results of the analysis Based on the experts, namely: linguists, material experts, and media experts determine statistical teaching materials based on problembased learning criteria meet the criteria with an average score of 0.76. Based on the analysis of teacher and student worksheets consisting of 9 people obtained from problem-based learning based statistical teaching materials meet the requirements with an average score of 95\%, so that learning materials can be improved based on statistical problems Problem Based Learning requires valid, practical criteria and can be used in learning.
\end{abstract}

Keywords: Dev elopment, Mathematic Teaching Materials, Problem Based Learning

Copyright (c) 2021 Fida Lestari, Asep Sukenda Egok, Riduan Febriandi

$\triangle$ Corresponding author : Asep Sukenda Egok, M.Pd.

Address : Jalan Pioner No. 110 Kel. Majapahit Lubuklinggau Timur 1 ISSN 2580-3735 (Media Cetak)

Email : asep.egok91@ gmail.com ISSN 2580-1147 (Media Online)

DOI: https://doi.org/10.31004/basicedu.v5i1.628 
396 Pengembangan Bahan Ajar Matematika Berbasis Problem Based Learning Pada Siswa Sekolah Dasar Fida Lestari, Asep Sukenda Egok, Riduan Febriandi

DOI: https://doi.org/10.31004/basicedu.v5i1.628

\section{PENDAHULUAN}

Pendidikan adalah suatu usaha yang dilakukan untuk mengembangkan kemampuan dan kepribadian individu melalui proses atau kegiatan tertentu (pengajaran, bimbingan atau latihan) serta interaksi individu dengan lingkungannya untuk mencapai manusia seutuhnya (Arifin, 2012). Oleh karena itu, pendidikan merupakan suatu hal yang sangat penting dalam meningkatkan sumber daya manusia. Guru adalah salah satu komponen yang sangat penting dalam pelaksanaan pendidikan karena guru bertatap langsung dengan peserta didik dalam proses pembelajaran yang di dalam proses kegiatannya terjadi pentransferan ilmu pengetahuan serta penanaman nilai-nilai moral melalui bimbingan dari seorang pendidik.

(Sunhaji, 2014:32) Proses pembelajaran suatu usaha untuk membuat siswa belajar, sehingga situasi tersebut merupakan peristiwa belajar (even of learning) yaitu usaha untuk terjadinya perubahan tingkah laku dari siswa, Perubahan tingkah laku dapat terjadi karena adanya interaksi antara siswa dengan lingkungannya. Selama ini proses pembelajaran khususnya pembelajaran matematika yang dilaksanakan oleh guru masih menggunakan pembelajaran yang lebih menekankan pada hafalan dan mencari satu jawaban yang benar untuk soalsoal yang diberikan, proses pemikiran tingkat tinggi dan kreatifitas kurang dilatih. Sehingga siswa kurang termotivasi untuk belajar Matematika. Oleh karena itu, sebagai seorang guru dituntut harus mampu mengajar dengan baik dan menarik serta mampu menciptakan proses pembelajaran yang bervariasi misalnya kreatif dalam memadukan model pembelajaran, menyesuaikan dengan keadaan peserta didik dan memilih bahan ajar yang tepat dalam pembeajaran Matematika. Oleh sebab itu, perlu adanya perbaikan dan peningkatan dalam pembelajaran
Matematika seperti bahan ajar yang menarik dan inovatif agar siswa termotivasi dan tertarik untuk belajar Matematika.

(Hasanah, 2012:115) mengemukakan bahwa sumber belajar merupakan informasi yang disajikan dan disimpan dalam berbagai bentuk media, yang dapat membantu siswa dalam belajar sebagai perwujudan dari kurikulum, bentuknya tidak terbatas apakah dalam bentuk cetakan, video, format perangkat lunak atau kombinasi dari berbagai format yang dapat digunakan oleh siswa ataupun guru. Proses pembelajaran dalam kurikulum 2013 harusnya berpusat pada peserta didik dan pendidik hanya sebagai fasilitator. Oleh karena itu, didalam proses pembelajaran guru diharapkan tidak hanya menggunakan satu model, metode, media pebelajaran dan sumber belajar saja melainkan memakai model, metode, media pembelajaran dan sumber belajar yang inovatif dan menarik dengan tujuan agar bisa menumbuhkan semangat dan motivasi peserta didik agar lebih aktif dan kreatif.

Adapun permasalahan yang terjadi disalah satu Sekolah Dasar yaitu guru masih menerapkan pembelajaran yang konvensional, bahan pembelajaran yang digunakan masih sangat minim, seperti yang kita ketahui bahwa bahan ajar ini sudah menjadi penunjang atau alat bantu pendidik untuk mentransferkan materi dan memberikan soal-soal maupun tugas kepada peserta didik. Tetapi pada kenyataannya bahan ajar yang dipakai sulit dipahami peserta didik, kurang menarik dan peserta didik kurang mampu memahami maksud dari soal-soal yang terdapat di dalam bahan ajar tersebut, dari permasalahan tersebut mempengaruhi hasil belajar siswa kelas $\mathrm{V}$ yang belum maksimal. Untuk mencapai proses pembelajaran yang maksimal pendidik diharapkan mampu menciptakan proses pembelajaran yang bisa memotivasi dan mengaktifkan peserta didik 
397 Pengembangan Bahan Ajar Matematika Berbasis Problem Based Learning Pada Siswa Sekolah Dasar Fida Lestari, Asep Sukenda Egok, Riduan Febriandi

DOI: https://doi.org/10.31004/basicedu.v5i1.628

dalam proses pembelajaran. Sehingga dari permasalahan yang terjadi dapat memungkinkan saya sebagai peneliti mampu menghasilkan produk bahan ajar yang signifikan diharapkan oleh peserta didik untuk meningkatkan hasil afektif maupun kognitif peserta didik dalam proses pembelajaran, khususnya dalam pembelajaran matematika. Untuk memfasilitasi peningkatan hasil belajar matematika peserta didik perlu didukung oleh model pembelajaran yang tepat sehingga tujuan pembelajaran dapat tercapai sesuai dengan apa yang diharapkan. Menurut Sumartini (Nurhidayati, dkk., 2017:238) mengemukakan bahwa salah satu model pembelajaran yang dianggap dapat menfasilitasi kemampuan penalaran siswa adalah pembelajaran berbasis masalah (Problem Based Laearning).

Berdasarkan uraian latar belakang di atas, perlu dilakukan pengembangan bahan ajar dengan menggunakan model pembelajaran Problem Based Learning agar bisa mengatasi permasalahan belajar peserta didik dan mampu mengembangkan kreatifitas dan keaktifan peserta didik pada pelajaran matematika yang sedang terjadi di Sekolah Dasar tersebut. Maka peneliti tertarik untuk melakukan penelitian yang berjudul "Pengembangan Bahan Ajar Matematika Berbasis Problem Based Learning pada Siswa Kelas V Sekolah Dasar".

\section{METODE}

Peneliti mengembangkan bahan ajar dengan menggunakan metode penelitian Research and Development (R\&D). (Kharisma \& Asman, 2018:38) menyatakan bahwa penelitian pengembangan (Research and Development) merupakan penelitian yang bertujuan untuk menghasilkan produk dengan kualitas valid dan praktis ditinjau dari kemampuan pemecahan masalah dan prestasi belajar peserta didik.
Penelitian ini menghasilkan produk berupa bahan ajar Mathematic dengan menggunakan model Problem Based Learning (PBL) tentang materi statistika.

Bahan Ajar ini dikembangkan melalui beberapa tahapan diantaranya dengan menggunakan model pengembangan 4-D yaitu tahap 1) Tahap define (pendefinisian), 2) Tahap design (perencanaan), 3) Tahap develop (pengembangan), 4) Tahap disseminate (penyebaran), tetapi pada pengembangan ini peneliti hanya sampai tahap pengembangan.

\section{Teknik Pengumpulan Data}

a. Wawancara

(Mahmud, 2011:173) menyatakan bahwa wawancara adalah teknik pengumpulan data dengan mengajukan pertanyaan kepada responden dan mencatat atau merekam jawaban-jawaban responden. Didukung oleh pendapat (Sugiyono, 2010:194) mengemukakan bahwa wawancara digunakan sebagai teknik pengumpulan data apabila peneliti ingin melakukan studi pendahuluan untuk menemukan permasalahan yang harus ditelitidan juga apabila peneliti ingin mengetahui hal-hal dari responden yang lebih mendalam dan jumlah respondennya sedikit/kecil.

Berdasarkan beberapa pendapat ahli di atas dapat disimpulkan bahwa wawancara merupakan salah satu teknik atau cara yang digunakan oleh seorang peneliti untuk memperoleh beberapa informasi dari narasumber agar informasi yang belum diketahui bisa kita ketahui. Wawancara ini dilakukan oleh peneliti dengan mengajukan beberapa pertanyaan kepada guru dan siswa sehingga mendapatkan informasi yang dibutuhkan oleh peneliti.

b. Angket

(Sugiyono, 2015:199) mengemukakan bahwa Angket merupakan teknik pengumpulan data yang dilakukan dengan cara memberi seperangkat 
398 Pengembangan Bahan Ajar Matematika Berbasis Problem Based Learning Pada Siswa Sekolah Dasar Fida Lestari, Asep Sukenda Egok, Riduan Febriandi

DOI: https://doi.org/10.31004/basicedu.v5i1.628

pertanyaan atau pernyataan tertulis kepada responden untuk dijawabnya. Dari pendapat tersebut dapat disimpulkan bahwa angket atau kuesioner adalah suatu teknik atau cara yang digunakan seorang peneliti untuk memperoleh informasi dari responden yang berupa pertanyaan atau pernyataan dibuat dari awal sehingga dapat mencapai tujuan yang diinginkan. Langkah selanjutnya setelah memperoleh informasi dari responden yaitu cara untuk mengukur respon responden atau peserta didik terhadap bahan ajar Mathematic yang telah dibuat selanjutnya hasil angket yang berupa pertanyaan tersebut dianalisis dengan menggunakan skala Likert dan skala Guttman.

\section{Teknik Analisis Data}

Peneliti menggunakan analisis deskriptif kuantitatif untuk mengelola data dalam penelitian ini. Statistik deskriptif adalah statistik yang digunakan untuk mengidentifikasi data dan mendeskripsikan data yang telah terkumpul. Sesuai dengan pendapat (Sugiyono, 2014:29) Statistik deskriptif berfungsi untuk mendeskripsikan atau memberi gambaran terhadap obyek yang diteliti melalui data sampel atau populasi sebagaimana adanya, tanpa melakukan analisis dan membuat kesimpulan yang berlaku untuk umum. Berdasarkan pendapat tersebut dapat dipahami bahwa statistik ini berfungsi untuk memberikan informasi hingga data yang diperoleh peneliti bisa digunakan oleh orang lain, yang meliputi analisis kelayakan, respon siswa, dan penilaian jawaban siswa pada bahan ajar yang telah dibuat sebelumnya.

a. Uji Kevalidan Bahan Ajar

Arikunto dalam (Rijal \& Egok, 2019:366) mengemukakan bahwa validitas adalah suatu ukuran yang menunjukkan tingkat-tingkat kevalidan atau kesahihan sesuatu instrumen, sebuah instrumen dikatakn valid apabila mampu mengukur apa yang diinginkan apabila dapat mengungkapkan data dari variabel yang diteliti secara tepat. Uji validitas pada tahap ini adalah validitas teoritik yaitu validasi yang dilakukan oleh para ahli dibidangnya. Karakteristik yang akan divalidasi yaitu: bahasa, materi, dan media, validator tersebut menganalisis bahan ajar yang dirancang dan memberikan saran serta masukan pada rancangan bahan ajar. Lembar penilaian akan menghasilkan data yang akan digunakan untuk menentukan kevalidan produk berupa bahan ajar dengan menggunakan model Problem Based Learning (PBL). Data penilaian kevalidan bahan ajar diperoleh dari dosen ahli bahasa, ahli materi dan ahli media, data lembar penilaian kevalidan bahan ajar diidentifikasi dengan langkah-langkah sebagai berikut:

1) Memberikan skor untuk setiap item dengan jawaban sangat baik (4), baik (3), tidak baik (2), dan sangat tidak baik (1).

2) Pemberian nilai validitas dengan rumus berikut:

$$
\mathrm{V}=\sum S /[\mathrm{n}(\mathrm{c}-1)]
$$

(Azwar, 2015:113)

\section{Keterangan:}

$\mathrm{S}=\mathrm{r}-\mathrm{lo}$

Lo = Angka penilaian validitas yang terendah (dalam hal ini $=1)$

c = Angka penilaian validitas yang tertinggi $($ dalam hal ini $=5)$

$r$ = Angka yang diberikan oleh seorang penilai

3) Mencocokkan rata-rata validitas dengan kriteria kevalidan bahan ajar.

Tabel 1 Interpretasi Validitas Aiken's V

\begin{tabular}{|c|c|}
\hline Koefisien Korelasi & Interpretasi Validitas \\
\hline$>0,80$ & Tinggi \\
\hline $0,60 \leq V<0,80$ & Cukup Tinggi \\
\hline $0,40 \leq V<0,60$ & Cukup \\
\hline $0 \leq V<0,40$ & Buruk \\
\hline
\end{tabular}

(Febriandi, dkk. 2019:152) 
399 Pengembangan Bahan Ajar Matematika Berbasis Problem Based Learning Pada Siswa Sekolah Dasar Fida Lestari, Asep Sukenda Egok, Riduan Febriandi

DOI: https://doi.org/10.31004/basicedu.v5i1.628

\section{b. Uji Kepraktisan Bahan Ajar}

Menurut (Arifin, 2012:264) mengemukakan bahwa kepraktisan adalah syarat suatu tes standar. kepraktisan bahan ajar dengan menggunakan model Problem Based Learning (PBL) dapat dilihat dari hasil identifikasi angket kepraktisan siswa dan guru Hasil penilaian pada siswa dan guru pada lembar kepraktisan dicari dengan cara berikut:

1) Angket respon siswa diberikan skor untuk setiap item dengan jawaban "Ya" (1) dan "Tidak" (0). Sedangkan untuk angket respon guru diberikan skor sangat setuju (4), setuju (3), tidak setuju (2), sangat tidak setuju (1).

2) Pemberian nilai kepraktisan dengan rumus berikut:

$$
\mathrm{TK}=\frac{\text { Jumlah skoryang diperoleh }}{\text { jumlah skor total }} \times 100 \%
$$

(Hidayat \& Irawan, 2017)

Tabel 2 Kriteria Kepraktisan Bahan Ajar

\begin{tabular}{|c|c|}
\hline Interval Rata-rata Skor & Klarifikasi \\
\hline $81 \%-100 \%$ & Sangat Praktis \\
\hline $61 \%-80 \%$ & Praktis \\
\hline $41 \%-60 \%$ & Cukup Praktis \\
\hline $21 \%-40 \%$ & Kurang Praktis \\
\hline $0 \%-20 \%$ & Tidak Praktis \\
\hline
\end{tabular}

Riduan dalam (Hidayat \& Irawan, 2017:56)

\section{HASIL DAN PEMBAHASAN}

Berdasarkan hasil penelitian, diperoleh produk penelitian berupa bahan ajar Matematika berbasis Problem Based Learning yang membahas materi statistika. Bahan ajar ini dikembangkan dengan menggunakan model pengembangan 4-D yang terdiri dari tahap pendefinisian (define), perancangan (design), dan pengembangan (develop). Pembahasan dalam penelitian ini merupakan deskripsi dari hasil penelitian yag dilakukan dalam menguji validitas dan praktikalitas bahan ajar Matematika yang dikembangkan. Adapun tahapan proses desain pengembangan bahan ajar Matematika berbasis Problem Based Learning sebagai berikut:

\section{Tahap Pendefinisian (Define)}

Tahap Pendefinisian (Define) merupakan tahap analisis, ada beberapa langkah analisis yang dilakukan oleh peneliti pada tahap ini, diantaranya: analisis awal, analisis siswa, analisis tugas, analisis konsep, dan analisis tujuan pembelajaran. Berdasarkan analisis awal yang telah dilakukan dapat diketahui bahwa Kurikulum yang digunakan di SD Negeri 37 Lubuklinggau adalah Kurikulum 2013. Kemudian ditemui beberapa permasalahan dalam pembelajaran Matematika, yaitu Metode mengajar yang digunakan oleh guru kelas V SD Negeri 37 Lubuklinggau masih mengajar menggunakan sistem konvensional, proses pembelajaran Matematika masih berpusat pada guru (teacher centered), tidak menggunakan bahan ajar tambahan. Keadaan seperti ini berdampak buruk terhadap siswa, sehingga siswa menjadi kurang aktif, mandiri dan kreatif dalam pembelajaran. Selain itu, masalah materi pembelajaran Matematika statistika yang sedikit susah untuk dipahami siswa, untuk itu guru harus mampu memfasilitasi dan mengaitkan dengan masalah nyata dalam kehidupan sehari-hari agar siswa dapat memahami dengan mudah materi pembelajaran statistika. Kemudian, buku Matematika kelas V yang digunakan oleh guru masih kurang cakupan materinya, kurang menarik minat siswa untuk memecahkan masalah, serta soal-soal di dalam bahan ajar tersebut sulit dimengerti oleh siswa, sehingga guru dituntut untuk lebih kreatif dan inovatif dalam proses pembelajaran.

Maka dari itu, solusi yang bisa digunakan adalah penggunaan bahan ajar Matematika berbasis Problem Based Learning dikarenakan 
400 Pengembangan Bahan Ajar Matematika Berbasis Problem Based Learning Pada Siswa Sekolah DasarFida Lestari, Asep Sukenda Egok, Riduan Febriandi

DOI: https://doi.org/10.31004/basicedu.v5i1.628

bahan ajar ini bisa menarik perhatian siswa dengan tampilan yang tidak membosankan dan membantu siswa agar mudah memahami materi pembelajaran. Bahan ajar ini juga didukung dengan berbasis Problem Based Learning yang dapat melibatkan siswa secara aktif, kreatif, dan mempunyai keterampilan dalam memecahkan permasalahan yang terkait dengan materi statistika.

\section{Tahap Perancangan (Design)}

Tahap perancangan merupakan tahap yang kedua, terdiri dari 4 langkah yaitu penyusunan tes acuan patokan, pemilihan media, pemilihan format, dan desain awal. Pertama, dimulai dari tahap penyusunan tes acuan patokan, tahap ini peneliti membuat soal-soal untuk digunakan dalam bahan ajar yang berkaitan dengan materi statistika. Soal yang dibuat terdiri dari soal latihan dengan menemukan yang diberikan kepada siswa dan dikerjakan secara berkelompok atau diskusi. Soal tugas individu berupa isian dan uraian dengan mencari jawaban soal secara individu. Dilanjutkan dengan tahap yang kedua yaitu pemilihan media, pada tahap ini peneliti memilih bahan ajar sebagai media yang digunakan untuk mempermudah dalam penyampaian materi pembelajaran kepada siswa. Kemudian penulisan bahan ajar ini menggunakan format yang berbasis Problem Based Learning serta materi yang ada pada bahan ajar sesuai dengan kompetensi dasar kurikulum 2013 yaitu materi statistika sehingga tersusunlah desain awal berupa bahan ajar draf 1 .

\section{Tahap Pengembangan (Develop)}

Pelaksanaan pada tahap pengembangan ini ialah melakukan validasi bahan ajar oleh para ahli diikuti dengan revisi dan uji coba one to one, small group, dan uji kepraktisan guru untuk mengetahui kepraktisan dari bahan ajar yang dikembangkan. Adapun pembahasan proses validitas dan praktikalitas sebagai berikut: a. Validitas Bahan Ajar Matematika Berbasis

\section{Problem Based Learning}

Bahan ajar Matematika yang telah dikembangkan telah dianalisis oleh 3 ahli dibidangnya, diantaranya ahli bahasa, ahli materi, dan ahli media. Validasi memberikan penilaian dan juga masukan terhadap bahan ajar Matematika berbasis Problem Based Learning yang telah dirancang, dari hasil validasi masih banyak kekurangan bahan ajar yang dikembangkan. Revisi dilakukan sesuai dengan masukan dan saran ahli yang telah memvalidasi bahan ajar Matematika yang dikembangkan, dari materi pembelajaran yang ada di dalam bahan ajar, tata bahasa dan penulisan, tata letak gambar, warna, atau animasi yang digunakan, soal-soalnya yang digunakan dalam evaluasi pembelajaran, dan bahan ajar berbasis Problem Based Learning.

Meskipun masih terdapat kekurangan dalam bahan ajar Matematika berbasis Problem Based Laearning yang dikembangkan, validator menilai bahwa penyajian bahan ajar Matematika yang telah didesain secara keseluruhan valid untuk digunakan di kelas V SD karena di dalamnya memuat materi yang dirancang dengan menggunakan model pembelajaran Problem Based Laearning dan disusun secara sistematis dan ringkas. Berdasarkan hasil analisis penilaian kevalidan bahan ajar oleh para ahli bahan ajar Matematika berbasis Problem Based Learning ini memperoleh respon sangat baik dilihat dari hasil penilaian validator terhadap bahan ajar Matematika berbasis Problem Based Learning yang dikategorikan cukup tinggi atau sama dengan valid, serta layak untuk diuji cobakan dengan beberapa perbaikan sesuai masukan dan saran dari ketiga ahli validator. Hasil revisi bahan ajar oleh para validator dapat dilihat pada gambar berikut. 
401 Pengembangan Bahan Ajar Matematika Berbasis Problem Based Learning Pada Siswa Sekolah DasarFida Lestari, Asep Sukenda Egok, Riduan Febriandi

DOI: https://doi.org/10.31004/basicedu.v5i1.628

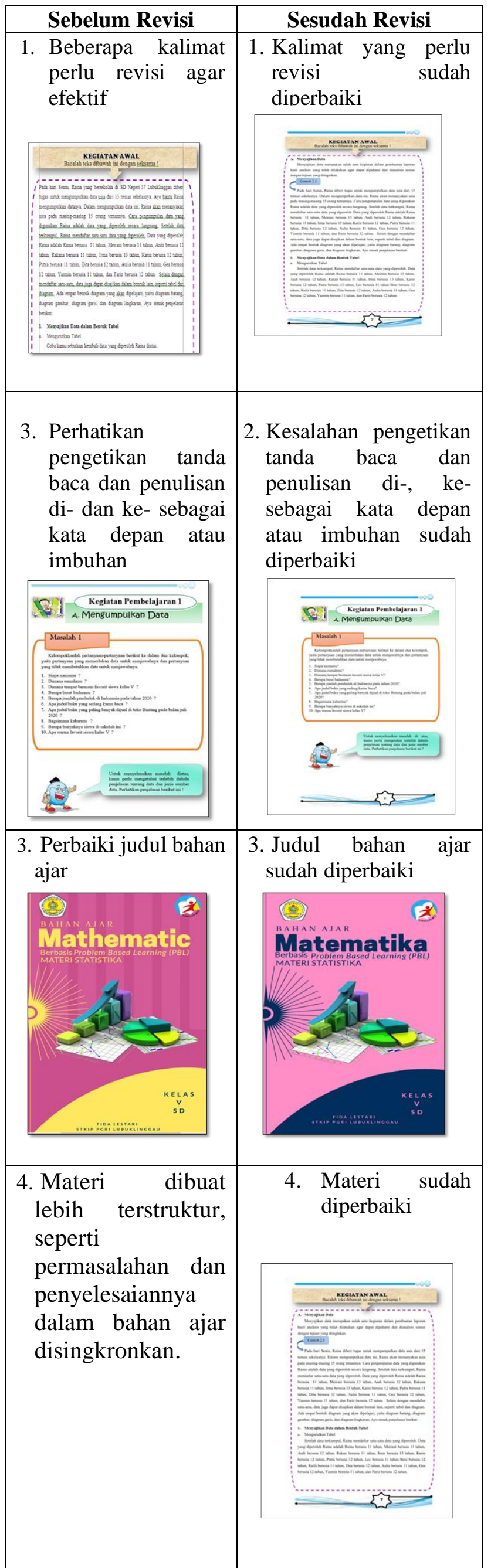

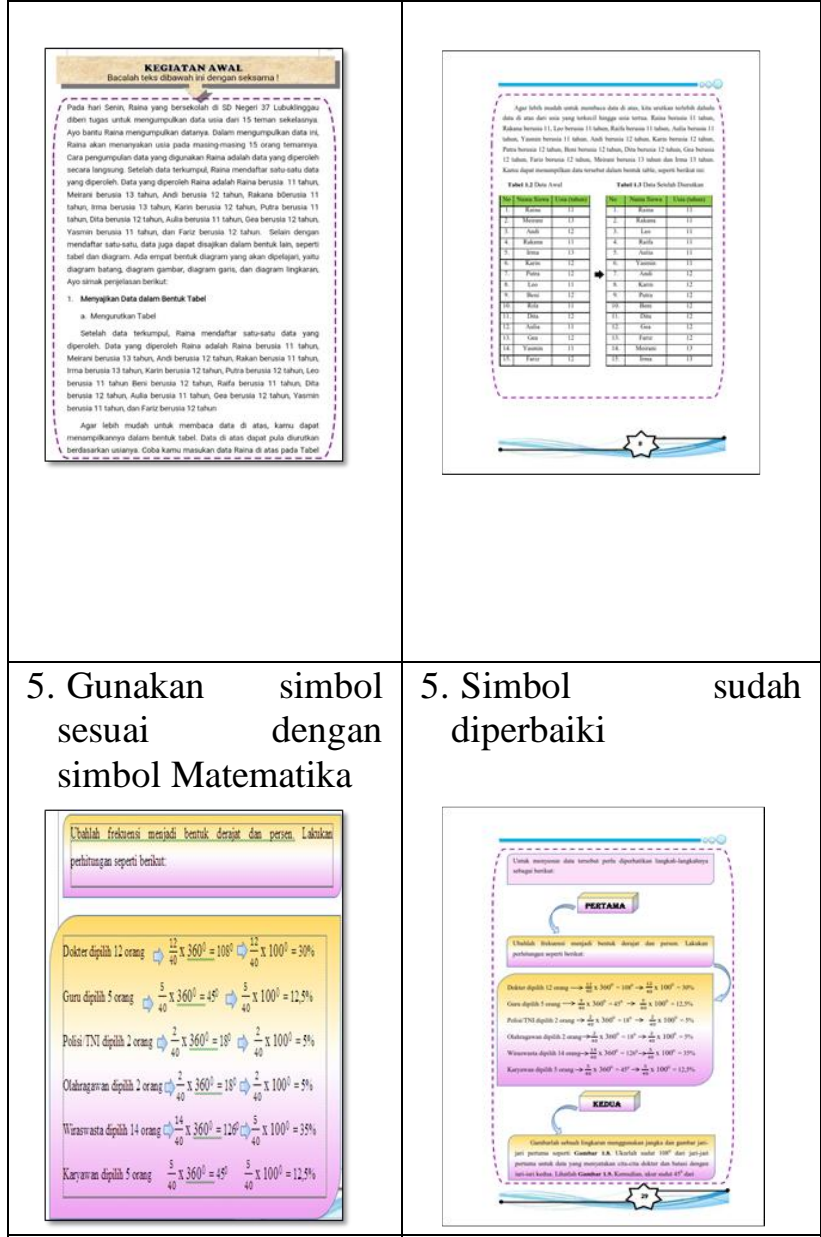

6. Materi dan contoh 6. Materi dan contoh gunakan permasalahan dalam kehidupan sehari-hari.
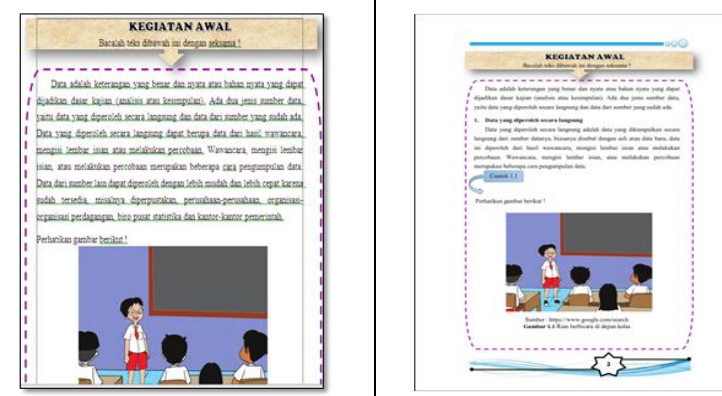

7. Terdapat beberapa 7 kekurangan pengambilan warna latar sehingga tulisan menjadi kurang terlihat
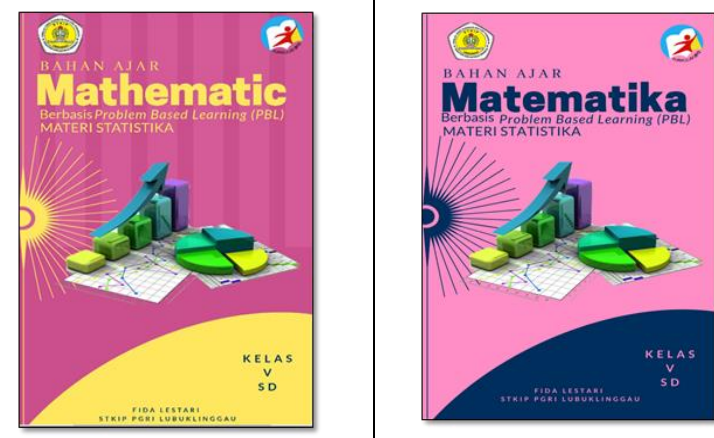
402 Pengembangan Bahan Ajar Matematika Berbasis Problem Based Learning Pada Siswa Sekolah DasarFida Lestari, Asep Sukenda Egok, Riduan Febriandi

DOI: https://doi.org/10.31004/basicedu.v5i1.628

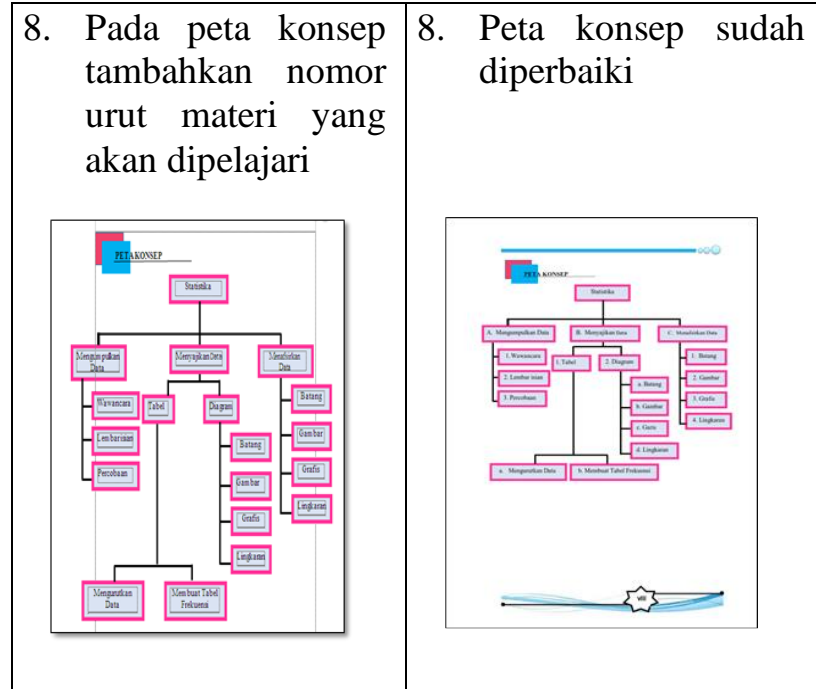

Hasil penilaian dari ketiga ahli dianalisis dengan menggunakan formula Aiken's $V$ untuk mengetahui validitas bahan ajar Matematika berbasis Problem Based Learning untuk siswa kelas V Sekolah Dasar yang telah dikembangkan. Hasilnya bisa dilihat pada uraian berikut ini:

\section{a. Ahli Bahasa}

Hasil dari penilaian ahli bahasa dianalisis dengan menggunakan formula Aiken's $V$ untuk mengetahui validitas bahan ajar Matematika berbasis Problem Based Learning untuk siswa kelas V SD pada materi statistika yang disusun dan dikembangkan. Adapun hasil validasi yang telah dianalisis dengan menggunakan formula Aiken's $V$ tersebut disajikan dalam bentuk Tabel 3 yang tersusun berdasarkan aspek yang dinilai.

Tabel 3

Hasil Analisis Validasi Ahli Bahasa menggunakan Aiken'V

\begin{tabular}{|c|c|c|c|c|}
\hline $\begin{array}{c}\text { Aspek } \\
\text { yang } \\
\text { dinilai }\end{array}$ & $\begin{array}{l}\text { Indikator } \\
\text { Penilaian }\end{array}$ & $\begin{array}{c}\text { Banyak } \\
\text { Butir }\end{array}$ & $\begin{array}{c}\text { Angka } \\
\text { Aiken's } \\
\text { V }\end{array}$ & $\begin{array}{l}\text { Kriteria } \\
\text { Koofisien } \\
\text { s Aiken's } \\
V\end{array}$ \\
\hline \multirow{4}{*}{$\begin{array}{l}\text { Kelayaka } \\
\text { n Bahasa }\end{array}$} & Lugas & 3 & 0,7 & $\begin{array}{l}\text { Cukup } \\
\text { Tinggi }\end{array}$ \\
\hline & $\begin{array}{l}\text { Komunika } \\
\text { tif }\end{array}$ & 1 & 0.7 & $\begin{array}{l}\text { Cukup } \\
\text { Tinggi }\end{array}$ \\
\hline & $\begin{array}{l}\text { Dialogis } \\
\text { dan } \\
\text { interaktif }\end{array}$ & 1 & 0.7 & $\begin{array}{l}\text { Cukup } \\
\text { Tinggi }\end{array}$ \\
\hline & $\begin{array}{l}\text { Kesesuaia } \\
\mathrm{n} \text { dengan } \\
\text { perkemba } \\
\text { ngan } \\
\text { peserta }\end{array}$ & 3 & 0,7 & $\begin{array}{l}\text { Cukup } \\
\text { Tinggi }\end{array}$ \\
\hline
\end{tabular}

\begin{tabular}{|l|l|l|l|l|}
\hline & didik & & & \\
\cline { 2 - 5 } $\begin{array}{l}\text { Kesesuaia } \\
\text { n dengan } \\
\text { kaidah } \\
\text { bahasa }\end{array}$ & 6 & 0,7 & $\begin{array}{l}\text { Cukup } \\
\text { Tinggi }\end{array}$ \\
\cline { 2 - 4 } & & & & \\
\hline
\end{tabular}

\section{b. Ahli Materi}

Adapun hasil validasi yang telah dianalisis dengan menggunakan formula Aiken's $V$ tersebut disajikan dalam bentuk Tabel 4 yang tersusun berdasarkan aspek yang dinilai.

Tabel 4

Hasil Analisis Validasi Ahli Materi menggunakan Aiken's $V$

\begin{tabular}{|c|c|c|c|c|}
\hline $\begin{array}{c}\text { Aspek } \\
\text { yang } \\
\text { dinilai }\end{array}$ & $\begin{array}{l}\text { Indikator } \\
\text { Penilaian }\end{array}$ & $\begin{array}{c}\text { Banyak } \\
\text { Butir }\end{array}$ & $\begin{array}{l}\text { Angk } \\
\text { a } \\
\text { Aiken } \\
\text { 's } V\end{array}$ & $\begin{array}{c}\text { Kriteria } \\
\text { Koofesien } \\
\text { Aiken's V }\end{array}$ \\
\hline \multirow{4}{*}{$\begin{array}{c}\text { Kelayak } \\
\text { an isi }\end{array}$} & $\begin{array}{l}\text { Kesesuaian } \\
\text { materi } \\
\text { dengan KD }\end{array}$ & 3 & 0,8 & Tinggi \\
\hline & $\begin{array}{l}\text { Keakuratan } \\
\text { materi }\end{array}$ & 4 & 0,85 & Tinggi \\
\hline & $\begin{array}{l}\text { Kemutakhir } \\
\text { an materi }\end{array}$ & 2 & 1 & Tinggi \\
\hline & $\begin{array}{l}\text { Mendorong } \\
\text { keingintahu } \\
\text { an }\end{array}$ & 2 & 0,85 & Tinggi \\
\hline \multirow{2}{*}{$\begin{array}{c}\text { Aspek } \\
\text { kelayak } \\
\text { an }\end{array}$} & $\begin{array}{l}\text { Teknik } \\
\text { penyajian }\end{array}$ & 1 & 0,7 & $\begin{array}{l}\text { Cukup } \\
\text { Tinggi }\end{array}$ \\
\hline & $\begin{array}{l}\text { Pendukung } \\
\text { penyajian }\end{array}$ & 4 & 0,85 & Tinggi \\
\hline $\begin{array}{c}\text { Penyajia } \\
n\end{array}$ & $\begin{array}{l}\text { Penyajian } \\
\text { pembelajara } \\
\mathrm{n}\end{array}$ & 1 & 0,7 & $\begin{array}{l}\text { Cukup } \\
\text { Tinggi }\end{array}$ \\
\hline $\begin{array}{c}\text { Aspek } \\
\text { penilaia } \\
n\end{array}$ & $\begin{array}{l}\text { Kebenaran } \\
\text { isi atau } \\
\text { materi } \\
\end{array}$ & 3 & 0,8 & Tinggi \\
\hline $\begin{array}{c}\text { Problem } \\
\text { Based } \\
\text { Learnin } \\
g\end{array}$ & $\begin{array}{l}\text { Keruntutan } \\
\text { sistematika } \\
\text { materi }\end{array}$ & 2 & 0,85 & Tinggi \\
\hline \multicolumn{3}{|c|}{ V rata-rata } & 0,82 & Tinggi \\
\hline
\end{tabular}

\section{c. Ahli Media}

Adapun hasil validasi yang telah dianalisis dengan menggunakan formula Aiken's $V$ tersebut disajikan dalam bentuk Tabel 5 yang tersusun berdasarkan aspek yang dinilai. 
403 Pengembangan Bahan Ajar Matematika Berbasis Problem Based Learning Pada Siswa Sekolah DasarFida Lestari, Asep Sukenda Egok, Riduan Febriandi

DOI: https://doi.org/10.31004/basicedu.v5i1.628

Tabel 5

Hasil Analisis Validasi Ahli Media menggunakan Aiken's $V$

\begin{tabular}{|c|c|c|c|c|}
\hline $\begin{array}{c}\text { Aspek } \\
\text { yang } \\
\text { dinilai }\end{array}$ & $\begin{array}{l}\text { Indikator } \\
\text { Penilaian }\end{array}$ & $\begin{array}{c}\text { Banyak } \\
\text { butir }\end{array}$ & $\begin{array}{c}\text { Angka } \\
\text { Aiken's } \\
\text { V }\end{array}$ & $\begin{array}{c}\text { Kriteria } \\
\text { Koofesien } \\
\text { Aiken's V }\end{array}$ \\
\hline \multirow{3}{*}{$\begin{array}{c}\text { Kelayak } \\
\text { an } \\
\text { Kegrafi } \\
\text { ka }\end{array}$} & $\begin{array}{l}\text { Ukuran } \\
\text { bahan ajar }\end{array}$ & 2 & 1 & Tinggi \\
\hline & $\begin{array}{l}\text { Desain } \\
\text { Sampul } \\
\text { bahan ajar } \\
\text { (cover) }\end{array}$ & 7 & 0,64 & $\begin{array}{l}\text { Cukup } \\
\text { Tinggi }\end{array}$ \\
\hline & $\begin{array}{l}\text { Desain Isi } \\
\text { bahan ajar }\end{array}$ & 18 & 0,7 & $\begin{array}{l}\text { Cukup } \\
\text { Tinggi }\end{array}$ \\
\hline \multicolumn{3}{|c|}{$\mathrm{V}$ rata-rata } & 0,78 & Tinggi \\
\hline
\end{tabular}

\section{d. Penilaian Seluruh Validator}

Rekapitulasi hasil keseluruhan penilaian kevalidan dari ketiga ahli dapat dilihat pada Tabel 6

Tabel 6

\section{Hasil Penilaian Seluruh Validator}

\begin{tabular}{|l|l|l|l|l|}
\hline \multirow{2}{*}{ No } & \multirow{2}{*}{ Nama Ahli } & \multicolumn{3}{|c|}{ Skor yang diperoleh } \\
\cline { 3 - 5 } & & Bahasa & Materi & Media \\
\hline 1 & $\begin{array}{l}\text { Dr. Rusmana Dewi, } \\
\text { M. Pd }\end{array}$ & 0,7 & - & - \\
\hline 2 & $\begin{array}{l}\text { Maria Luthfiana, } \\
\text { M. Pd }\end{array}$ & - & 0,82 & - \\
\hline 3 & $\begin{array}{l}\text { Dr. Dodik } \\
\text { Mulyono, M. Pd }\end{array}$ & - & - & 0,78 \\
\hline \multirow{2}{*}{ Jumlah } & 0,7 & 0,82 & 0,78 \\
\hline Rata-rata & \multicolumn{3}{|c}{0,76} \\
\hline
\end{tabular}

\section{e. Hasil Seluruh Analisis Kepraktisan Bahan} Ajar

Berdasarkan keseluruhan penilaian kepraktisan bahan ajar yang diuji coba oleh guru dan siswa terhadap bahan ajar yang sudah dijelaskan di atas menunjukan bahwa bahan ajar Matematika berbasis Problem Based Learning untuk kelas V SD pada materi statistika yang telah disusun dikembangkan dan dihasilkan memperoleh skor rata-rata 95\% dengan kriteria sangat praktis. Dapat ditarik kesimpulan bahwa bahan ajar Matematika berbasis Problem Based Learning untuk siswa kelas V SD pada materi statistika dapat dikategorikan sangat praktis untuk digunakan dalam proses pembelajaran. Rekapitulasi hasil keseluruhan penilaian kepraktisan dari guru dan siswa dapat dilihat pada Tabel 7 di bawah ini.

Tabel 7

Hasil Seluruh Analisis Kepraktisan Bahan Ajar

\begin{tabular}{|c|l|c|c|c|c|}
\hline No & Penilai & $\begin{array}{c}\text { Jumlah } \\
\text { butir } \\
\text { pernyata } \\
\text { an }\end{array}$ & $\begin{array}{c}\text { Skor } \\
\text { yang } \\
\text { dipero } \\
\text { leh }\end{array}$ & $\begin{array}{c}\text { Persen } \\
\text { tase }\end{array}$ & Kriteria \\
\hline 1 & $\begin{array}{l}\text { Titin } \\
\text { Afrianti, } \\
\text { S.Pd }\end{array}$ & 22 & 22 & $100 \%$ & $\begin{array}{c}\text { Sangat } \\
\text { Praktis }\end{array}$ \\
\hline $\begin{array}{l}3 \text { Siswa } \\
\text { Kelas Vb } \\
\text { SD Negeri } \\
37\end{array}$ & 60 & 57 & $95 \%$ & $\begin{array}{l}\text { Sangat } \\
\text { Praktis } \\
\text { Lubukling } \\
\text { gau }\end{array}$ & $\begin{array}{l}6 \text { Siswa } \\
\text { Kelas Vb } \\
\text { SD Negeri } \\
37\end{array}$ \\
$\begin{array}{l}\text { Lubukling } \\
\text { gau }\end{array}$ & 120 & 113 & $94 \%$ & $\begin{array}{l}\text { Sangat } \\
\text { Praktis }\end{array}$ \\
\hline & & 192 & $95 \%$ & $\begin{array}{l}\text { Sangat } \\
\text { Praktis }\end{array}$ \\
\hline
\end{tabular}

\section{KESIMPULAN}

Berdasarkan hasil penelitian pengembangan bahan ajar berbasis Problem Based Learning pada materi statistika kelas $\quad \mathrm{V} \quad$ SD Negeri 37 Lubuklinggau tahun pelajaran 2019/2020, dapat ditarik kesimpulan antara lain: Penelitian pengembangan ini menghasilkan bahan ajar berbasis Problem Based Learning pada materi statistika. Penelitian ini dilakukan dengan menggunakan model pengembangan Four-D (4-D) yang terdiri dari 4 tahapan diantaranya yaitu tahap pendefinisian (define), perancangan (design), pengembangan (develop), dan penyebaran (disseminate). Tetapi karena keterbatasan waktu dan kondisi pandemi covid-19 yang terjadi pada saat ini, penelitian hanya menggunakan 3 tahapan saja yaitu tahap pendefinisian (define), perancangan (design), dan pengembangan 
404 Pengembangan Bahan Ajar Matematika Berbasis Problem Based Learning Pada Siswa Sekolah DasarFida Lestari, Asep Sukenda Egok, Riduan Febriandi

DOI: https://doi.org/10.31004/basicedu.v5i1.628

(develop). Pada tahap pendefinisian (define) ada beberapa langkah yang dilakukan yaitu analisis awal, analisis siswa, analisis tugas, analisis konsep, serta perumusan tujuan pembelajaran. Kemudian pada tahap perancangan (design) halhal yang dilakukan yaitu: penyusuna tes acuan patokan berdasarkan hasil analisis tugas dan konsep, pemilihan media berupa bahan ajar sebagai sarana dalam mencapai tujuan pembelajaran, pemilihan format, desain awal perangkat pembelajaran serta pembuatan instrumen untuk mengukur kualitas bahan ajar yang terdiri dari angket para ahli dan lembar kepraktisan guru dan siswa. Angket ahli digunakan untuk mengukur

kevalidan bahan ajar sedangkan lembar kepraktisan guru dan siswa untuk mengukur kepraktisan bahan ajar. Selanjutnya, pada tahap pengembangan, terdiri dari beberapa jenis kegiatan yaitu: pengembangan bahan ajar, validasi bahan ajar, revisi bahan ajar, serta uji coba ke lapangan. Setelah draft bahan ajar dikembangkan kemudian dilakukan validasi oleh ahli bahasa, ahli materi, dan ahli media untuk mengetahui kevalidan bahan ajar yang dikembanngkan. Lalu, bahan ajar direvisi sesuai masukan dan saran kemudian siap untuk diuji cobakan ke lapangan. Tahap uji coba dilakukan kepada guru dan siswa SD Negeri 37 Lubuklinggau pada tanggal $01 \mathrm{Mei}$ - 16 Mei 2020 untuk mengetahui kepraktisan bahan ajar.

Kualitas bahan ajar yang dikembangkan sebagai berikut:

a. Bahan ajar yang dikembangkan dikategorikan "valid" yang ditentukan berdasarkan hasil penilaian bahan ajar oleh ketiga ahli validator (ahli bahasa, ahli materi, dan ahli media).

b. Bahan ajar yang dikembangkan dikategorikan "sangat praktis" yang ditentukan berdasarkan hasil analisis lembar kepraktisan guru dan siswa kelas Vb SD Negeri 37 Lubuklinggau terhadap bahan ajar yang dikembangkan.

\section{DAFTAR PUSTAKA}

Arifin, Z. (2012). Evaluasi pembelajaran. Bandung: PT Remaja Rosdakarya.

Azwar, S. (2015). Reliabilitas dan Validitas, Yogyakarta: Pustaka Pelajar.

Febriandi, R. F., Susanta, A. S., \& Wasidi, W. W. (2019). Validitas Lks Matematika Dengan Pendekatan Saintifik Berbasis Outdoor Pada Materi Bangun Datar. Jurnal Pembelajaran Dan Pengajaran Pendidikan Dasar, 2(2), $148-158$.

Hasanah, A. (2012). Pengembangan Profesi Guru.Bandung: Pustaka Setia.

Hidayat, A., \& Irawan, I. (2017). Pengembangan lks berbasis rme dengan pendekatan problem solving untuk memfasilitasi kemampuan pemecahan masalah matematis siswa. Jurnal Cendekia: Jurnal Pendidikan Matematika, 1(2), 51-63.

Kharisma, J. Y., \& Asman, A. (2018). Pengembangan Bahan Ajar Matematika Berbasis Masalah Berorientasi pada Kemampuan Pemecahan Masalah Matematis dan Prestasi Belajar Matematika. Indonesian Journal of Mathematics Education, 1(1), 3446.

Mahmud. (2011). Metode Penelitian Pendidikan, Bandung: Pustaka Setia.

Nurhidayati, S., Tayeb, T., \& Abbas, B. (2017). Pengembangan Bahan Ajar Matematika Berbasis Masalah untuk Memfasilitasi Pencapaian Kemampuan Penalaran Pada Pokok Bahasan Perbandingan Kelas VII MTsN Model Makassar. Jurnal Matematika Dan Pembelajaran, 5(2), 236-250.

Rijal, A., \& Egok, A. S. (2019). Pengembangan 
405 Pengembangan Bahan Ajar Matematika Berbasis Problem Based Learning Pada Siswa Sekolah DasarFida Lestari, Asep Sukenda Egok, Riduan Febriandi

DOI: https://doi.org/10.31004/basicedu.v5i1.628

Bahan Ajar Membaca Berorientasi Strategi PQ4R Di Kelas IV Sekolah Dasar. Universitas Pahlawan. Jurnal Basicedu, 3(2), 355-371.

Sugiyono. (2014). Statistika untuk Penelitian. Bandung: Alfabeta.

Sugiyono. (2015). Metode Penelitian Pendidikan:(Pendekatan Kuantitatif, Kualitatif dan $R \& D)$. Bandung: Alfabeta.

Sugiyono. (2010). Metode Penelitian Pendidikan (Pendekatan Kuantitatif, Kualitatif, dan $R \&$ $D)$. Bandung: Alfabeta.

Sunhaji. (2014). Konsep Manajemen Kelas dan Implikasinya dalam Pembelajaran. Jurnal Kependidikan, II(2), 32-33. 